\title{
Identification of some Lecidea, Porpidia and Lecidella species (lichen-forming ascomycetes) distributed in Turkey by sequence analysis of rDNA ITS region
}

\section{Türkiye'de yayılıș gösteren bazı Lecidea, Porpidia ve Lecidella türlerinin (liken olușturan ascomycetes) rDNA ITS bölgesinin dizi analizi yöntemi ile tanımlanması}

\author{
Esin BAŞARAN ${ }^{1}, \quad$ Demet CANSARAN-DUMAN ${ }^{2}$, ilker BÜYÜK' ${ }^{1}, \quad$ Sümer ARAS ${ }^{1}$
}

\section{ABSTRACT}

Objective: The taxonomy of Lecidea is extremely complex because of the enormous morphological variation within and between species. The aim of this study was to analyse the rDNA (ITS) regions of Lecidea species and related genus called Lecidella and Porpidia which are widely spreaded in Anatolia, Turkey.

Methods: The ITS rDNA sequence information of 17 samples from 11 species which were collected from different provinces of Anatolia were generated. Some of the specimens from Lecidea, Lecidella, Lecanora and Porpidia genus were also taken from the GenBank (www.ncbi.nlm.nih.gov). The phylogenetic analysis was performed by the help of four different methods (NJ, ME, MP, UPGMA) and these different methods manifested similar results.

Results: Minimum-Evolution (ME) dendrogram revealed that species of Lecidea, Lecidella, Porpidia and Ganoderma sp. genus were distributed into four main branches. Ganoderma applanatum (GU256764) which was considered as outgroup formed one of the branches, while the other species were collected on the other branchs. Generally the species which belong to the same genus, combined in one branch towards to the origin. In accordance with the results derived from

\section{ÖZET}

Amaç: Lecidea cinsine ait türlerin taksonomisi tür içi ve türler arasındaki büyük morfolojik farklılıkların olması nedeniyle oldukça karmaşa göstermektedir. Bu çalıșma kapsamında, Lecidea türleri ve onunla ilișkili cinsler olarak bilinen ve Anadolu'da oldukça yaygın olan Lecidella ve Porpidia cins türlerine ait örneklere ait rDNA (ITS) bölgelerinin analiz edilmesi amaçlanmıștır.

Yöntemler: Anadolu'nun farklı bölgelerinden toplanan 11 türe ait 17 liken örneğine ait rDNA ITS dizi analizi verileri incelenmiștir. Diğer ülkelerde dağılım gösteren Lecidea, Lecidella, Lecanora ve Porpidia cinsine ait bazı türlerin sekans analizi bilgileri GenBank'dan (www.ncbi.nlm.nih.gov) alınmıștır. Filogenetik analizler dört farklı metotla (NJ, ME, MP, UPGMA) analiz edilmiștir ve analiz sonuçlarında olușturulan dört faklı filogenetik ağaçta da benzer sonuçlar elde edilmiștir.

Bulgular: Minimum-Evolution (ME) analizine göre oluşturan filogenetik agaca göre Lecidea, Lecidella, Porpidia ve Ganoderma cinslerine ait türlerin dört ana dala ayrılmıș olduğu tespit edilmiștir. Minimum-Evolution (ME) analizde Ganoderma applanatum (GU256764) türü dışgrup olarak kullanılmıștır ve çalıșilan tüm türlerden ayr bir dal olușturmuștur. Çalıșılan Lecidea ve onunla ilișkili cinslerin tür ayrımı karșılaștırıldığında genellikle ayn

${ }^{1}$ Ankara University, Faculty of Science, Biotechnology Section, Department of Biology, ANKARA, TURKEY

${ }^{2}$ Ankara University, Biotechnology Institute, ANKARA, TURKEY

DOI ID : 10.5505/TurkHijyen. 2015.23540

Bașaran E, Cansaran-Duman D, Büyük I, Aras S. Identification of some Lecidea, Porpidia and Lecidella species (lichen-forming ascomycetes) distributed in Turkey by sequence analysis of rDNA ITS region. Turk Hij Den Biyol Derg, 2015; 72(1): 45-58. 
molecular phylogenetic analysis, genus Lecidea is found closer Porpidia rather than Lecidella morphologically. Numerable 4100 nucleotides were obtained from DNA sequences of related region of studied samples. It was indicated that 177 nucleotides of those regions were stable (C), 747 nucleotides were variable (V). It was confirmed that there were transitions in 56 nucleotide pairs, tranversion in 54 nucleotide pairs of compared samples.

Conclusion: In this study, the results of phylogenetic analysis of the genus Lecidea and other similar groups were firstly evaluated and the results will not be only a guide but also will provide a resource for next researchers. ITS

Key Words: Lecidea, Lecidella, Porpidia, cinsine ait türler ana dala karșı bir dal olușturmușlardır. Moleküler filogenetik analizler sonucunda elde edilen sonuçlara göre Lecidea cinsi Lecidella cinsinden ziyade Porpidia cinsine daha yakın bulunmuștur. Çalıșılan örneklerden ilgili bölgelerinin DNA dizisinden 4100 nükleotit elde edilmiştir. Bu nükleotidlerin 177 tanesi korunmuș (C), 747 nükleotit farklılașmıș (V) olarak belirlenmiştir. 56 nükleotit çifti transitions, 54 nükleotit çiftide tranversion olarak tespit edilmiștir.

Sonuç: Bu çalıșma kapsamında Lecidea ve onunla ilișkili cinslerin filogenetik analizi literatürde ilk defa değerlendirilmiștir ve elde edilen sonuçların ileride yapılacak fungus türlerinin moleküler filogenetik yöntemlerle tanımlanması çalıșmalarına kaynak sağlayacağı düșünülmektedir.

Anahtar Kelimeler: Lecidea, Lecidella, Porpidia, ITS

\section{INTRODUCTION}

The lichen genus forming Lecidea Ach. (Lecideaceae, Ascomycota) is one of the most heterogeneous of Zahlbruckner's artificial system and a large number of genera have been separated from it, especially during the last 30 years (1). The taxonomy of Lecidea is extremely complex because of the enormous morphological variation within and between species. Some problems are associated with the discrepancies of morphological data. Most systematic studies on Lecidea have been concerned with saxicolous species groups, but a number of recent studies deal with the non-saxicolous species groups as well $(1-3)$.

During the 150 years following Erik Acharius initial description of Lecidea in 1803, this genus became the "garbage bin" for crustose lichen taxa with generally green algal photobionts, photobiontfree apothecial margins and hyaline and singlecelled ascospores. At its height, the genus had grown to include approximately 1600 species $(2,3)$.
Only in the second half of the last century efforts were started, most significantly by Hertel $(1,4)$ to revise the genus based on morphological, chemical, ecological, and biogeographical data. As currently circumscribed Lecidea (Lecideaceae) includes approximately 100 species whose within genus revision is currently under way (1). The species of this genus grow on rock with thalli that are thick to thin, continuous or composed of dispersed areoles. The members are often endolithic which appear white to ashy gray, orange or becoming orange because of iron compounds in the rock substrate. The genus Lecidea belongs to Lecideaceae includes photobiont green (Trebouxia). They have characteristic apothecia lecideine which is disks black or very dark brown, lightly or heavily coated with white pruina in some taxa. Their paraphyses are branched and netlike, not conspicuously expanded at the tips. Their epihymenium pigment is brown, olive or green. They have eight per spores per asci with a distinctive tube 
or cylinder in the tip. Their ascospores are one-celled which have colorless and large. Most of the species of this genus grow on siliceous or rarely calcareous rocks. A large percentage of crustose lichens on rock with large black apothecia (more than $0.75 \mathrm{~mm}$ in diameter) belong to this important genus. Other crustose lichens that are superficially similar with a hand lens include species of Lecidea, Rhizocarpon, Sarcogyne and Buellia (5).

To light on the clarification of the taxonomic status of Lecidea and related genera such as Porpidia and Lecidella, the sequence diversity in the internal transcribed spacer (ITS) region of nuclear ribosomal DNA was studied. Porpidia belongs to the largest group of the Lecanoromycetes. Porpidia, as well as the family Porpidiaceae, include exclusively crustose taxa that form colourful thalli on siliceous to slightly calcareous rock surfaces worldwide in association with their unicellular green algal photobionts of the genus Trebouxia (Chlorophyta) (6). Members of Porpidia are inhabitants of exposed to shaded, but always humid localities in temperate to arctic zones. The lichen genus Porpidia provides excellent opportunities for evolutionary, reproductive, and ecological studies of crustose epilithic lichen symbioses (3).

In its unclear taxonomic history Porpidia is closely entwined with the crustose genus Lecidea. One of the largest genera split from Lecidea is the genus Porpidia. Several revisions of the genus Porpidia based on traditionally employed morphological, chemical, ecological, and biogeographical characters exist (7-12). They are the most studied of the recent segregates of Lecidea $(2,8-11)$ but in spite of this, although it is usually easy to identify a lichen as a Porpidia, it is often very difficult, or impossible, to assign it to a particular species. Species concepts are still unclear within the genus with many of the characters used in separating taxa (e.g. chemistry, width of excipular hyphae) being revealed only after detailed microscopic/biochemical investigation. According to Buschbom and Mueller (3), it is probable that many of these problems are unresolvable by traditional taxonomic methods and that molecular techniques will be required to elucidate critical species boundaries.

The other related genus with Lecidea; the genus Lecidella was established by Körber (13). Zahlbruckner (14) placed it in Lecidea sect. Eu Lecidea. Hertel (4), restricted Lecidella to the Lecidella elaeochroma group which had been precisely characterized by Fries (15) and classified it as a subgenus of Lecidea. Hertel and Leuckert (16) revealed the special status of the taxon Lecidella by chemosystematic investigations and established it as a separate genus. In this respect the presence of derivatives of norlichexanthone in the taxon was recognized as a crucial character. The Lecidella thalli are gray but some with imperceptible thalli. Their apothecia are lecideine type which are pitch black, often shiny and with black margins level with the disk or prominent. The species of Lecidella grow on rocks (especially those containing calcium), bark, wood or soil (5). As to the infrageneric classification of the genus Lecidella for a long time it was based mainly on thallus colour and spot tests, which are both of limited value, and on morphological characters. As a result, many species were doubtful and their delimitations indistinct. By use of additional chemical and morphological characters it has been possible to overcome these obstacles (17 - 20). Important contributions to the chemistry of the genus were made by Huneck and Santesson (21) and Elix and Crook (22). 
In general, it is systematically difficult to determine crustose lichens and less informative for resolving phylogenetic problems of lichen genera. Development of molecular techniques has been asisted to determine genetic similarities in lichen species. Recent molecular studies have been mainly used to reveal phylogenetic relationships between the specimens. Some scientists have been widely used for reconstructing phylogenetic relationships from the overall genome similarity $(23,24)$. The spacer regions like the internal transcribed spacers (ITS) and external transcribed spacers (ETS) are widely utilized in phylogenetics studies. The fact, that these regions are present in many copies in the genome is an advantage for laboratory practice and might be useful tools for phylogenetic analysis. The internal transcribed spacer (ITS) is intercalated in the $18 \mathrm{~S}-5.8 \mathrm{~S}-28 \mathrm{~S}$ region separating the elements of the rDNA locus (25). One of the most preferred techniques to determine genetic relationship of lichens at lower taxonomic levels involves sequence diversity study of the ITS region of nuclear ribosomal DNA (26). The ITS region plays a role in ribosomal maturation and processing of small and large-subunit rDNAs (27). The evolutionary origin of the ITS is considered to be an intron-like structure flanked by highly conserved region from which universal primers can be obtained $(28,29)$. The small size of the ITS region makes this region easy to amplify, even from herbarium material that is dry. The other advantage in sequencing the ITS region is that it is non-coding and so includes a relatively high level of variability (27). Since its first application by Porter and Collins (30) in it has become widely used for phylogeny reconstruction.

It clearly indicates that the species concept in Lecidea needs revision and that molecular data are helpful in interpreting subtle morphological differences that have been previously regarded as intraspecific variability. It was investigated that ITS regions of Lecidea, Lecidella, and Porpidia lichen species for variability using PCR and automated sequencing. The identity of lichens from some Lecidea, Lecidella and Porpidia species has been determined by ITS rDNA sequence comparisons in order to estimate the diversity, to detect patterns of specificity. Specific PCR primers have been used to determine the ITS rDNA sequences from DNA extractions of dried lichens. There are 17 specimens from Lecidea, Lecidella, Lecidoma and Porpidia in Turkey as herbarium sample and in very small amounts. Other Lecidea, Lecidella and Porpidia lichen species recorded for Turkey were not available because most of the species were collected by foreign researchers in 1800s. The indicated locations of mentioned samples are not consistent with current settlement regions. Direct comparisons and phylogenetic analyses allowed the assignment of some Lecidea, Lecidella and Porpidia ITS rDNA phylogeny.

In this study, molecular techniques were applied on 17 samples of genus Lecidea, Lecidella, Lecidoma and Porpidia lichen which were collected from Anatolia, Turkey. 26 lichen samples related to Lecidea, Lecidella, Lecanora and Porpidia specimens were obtained from GenBank. Also Ganoderma applanatum (GU256764) was used to test reliability of analysis as a out-group. This is the first study with molecular markers and ITS sequence analysis on Lecidea and their related genuses which are Lecidella and Porpidia in Anatolia, Turkey and focused on revealing the genetic distances and also defining genotypes of the specimens of the species used in the study. 


\section{MATERIAL AND METHODS}

\section{Lichen materials}

A total of 17 samples were used in the present study including Lecidea (4), Lecidella (3), Porpidia (3) and Lecidoma (1) species. Lichen samples were collected from different parts of Anatolia, Turkey and Table 1 was shown in localities. The samples were dried at room temperature and foreign matters were removed prior to grinding. The lichen samples are stored in the Herbarium of Erciyes University (Erciyes University, Department of Botany, Kayseri, Turkey). Some of the lichen materials were provided from previously collected and stored material of Erciyes University Herbarium.

Table 1. Collection area of Lecidea, Lecidella, Porpidia and Lecidoma species

\begin{tabular}{|c|c|c|}
\hline Accession number & Name of sample & Location \\
\hline HQ605926 & Lecidea fuscoatra & Ankara, Beynam Forest, N 3653'920", E 3255’005”, 1450 m, 06.01.2009 \\
\hline HQ605929 & Lecidea fuscoatra & Bilecik, North of Çaltı village, N 4001'36", E 30¹4'17", 573 m, 23.07.2007 \\
\hline HQ605930 & Lecidea fuscoatra & Konya, Gevne village, N 3653'127", E 32¹9'124", 2100 m, 06.07.2007 \\
\hline HQ605928 & $\begin{array}{l}\text { Lecidea fuscoatra var. } \\
\text { grisella }\end{array}$ & $\begin{array}{l}\text { Trabzon, Of, Uzungöl province, N 40037'091”, E 40036'885”, } 1240 \text { m, } \\
\text { 30.10.2008 }\end{array}$ \\
\hline HQ605931 & $\begin{array}{l}\text { Lecidea fuscoatra var. } \\
\text { grisella }\end{array}$ & $\begin{array}{l}\text { Trabzon, Maçka, surround of the Sumela Monastery, } 1230 \mathrm{~m}, \mathrm{~N} 40^{\circ} 41^{\prime} 16^{\prime \prime} \text {, } \\
\text { E 39 39'37", } 29.10 .2008\end{array}$ \\
\hline KF570277 & Lecidea syncarpa & $\begin{array}{l}\text { Trabzon, Maçka, surround of the Sumela Monastery, } 1230 \mathrm{~m}, \mathrm{~N} 40^{\circ} 41^{\prime} 16^{\prime \prime} \text {, } \\
\text { E 39 39'37", } 29.10 .2008\end{array}$ \\
\hline KF570280 & Lecidea plana & $\begin{array}{l}\text { Trabzon, Maçka, surround of the Sumela Monastery, } 1230 \mathrm{~m}, \mathrm{~N} 40^{\circ} 41^{\prime} 16^{\prime \prime} \text {, } \\
\text { E 39 39'37"', } 29.10 .2008\end{array}$ \\
\hline HQ605936 & Lecidella elaeochroma & Trabzon, Of, Uzungöl, N 40037'091", E 40036’885”, 1240 m, 31.10.2008 \\
\hline HQ605938 & Lecidella elaeochroma & $\begin{array}{l}\text { Kayseri, Bakırdağ, Çataloluk village, N38¹1'326”, E 3550'605”, } 1400 \text { m, } \\
\text { 15.06.2007 }\end{array}$ \\
\hline HQ605932 & Lecidella patavina & $\begin{array}{l}\text { Sivas, Gürün, Gökpınar Village, N 38³9'111”, E 37¹8’374”, } 1562 \text { m, } \\
\text { 12.06. } 2007\end{array}$ \\
\hline HQ605934 & Lecidella patavina & $\begin{array}{l}\text { Niğde, Çamardı, Aladağlar National Park, Emli village, N } 37^{\circ} 45^{\prime} 886^{\prime \prime} \text { E } \\
35^{\circ} 06^{\prime} 454^{\prime \prime}, 1840 \text { m, 19.06.2007 }\end{array}$ \\
\hline HQ605935 & Lecidella stigmatea & $\begin{array}{l}\text { Rize, Çamlıhemşin, around of Zilkale, N 40058'389”, E 40057’505”, } 691 \\
\text { m, 30.10.2008 }\end{array}$ \\
\hline HQ605937 & Lecidella stigmatea & $\begin{array}{l}\text { Kayseri, Yahyalı Aladağlar National Park, Tekekalesi Dirsek village, N } 37 \\
\text { '050'279", E 35011’946”, 3320m, 19.06.2007 }\end{array}$ \\
\hline HQ605941 & Porpidia crustulata & $\begin{array}{l}\text { Trabzon, Of, Uzungöl-Soğanlı road,N 40036'117”, E 40016'682”, } 2210 \text { m, } \\
\text { 31.10.2008 }\end{array}$ \\
\hline HQ605940 & Porpidia macrocarpa & $\begin{array}{l}\text { Rize, Çamlıhemşin, Ayder plateau and Kavran plateau, N 40055'601", E } \\
41007^{\prime} 603 ", 1700 \text { m, 01.11.2008 }\end{array}$ \\
\hline HQ605939 & Porpidia musiva & $\begin{array}{l}\text { Trabzon, Of, Uzungöl-Soğanlı road, N 40036'117", E 40016'682", } 2210 \text { m, } \\
\text { 29.10.2008 }\end{array}$ \\
\hline KF570278 & Lecidoma demissum & $\begin{array}{l}\text { Trabzon, Maçka, surround of the Sumela Monastery, } 1230 \mathrm{~m}, \mathrm{~N} 40^{\circ} 41^{\prime} 16^{\prime \prime} \text {, } \\
\text { E } 39^{\circ} 39^{\prime} 37^{\prime \prime}, 29.10 .2008\end{array}$ \\
\hline
\end{tabular}


DNA extraction, ITS amplification and sequencing

Total DNA was extracted from thallus or apothecia bu using DNA isolation protocol of herbarium material on lichen species (31). This protocol gives a high quality DNA, free of polysaccharides and other metabolites which might interfere with restriction endonucleases. In particular: lichen material $(0.1 \mathrm{~g})$ was ground to a fine powder in liquid nitrogen. Prewarmed extraction buffer $[50 \mathrm{mM}$ Tris-HCL $(\mathrm{pH}$ 8), $50 \mathrm{mM}$ EDTA, $0.8 \mathrm{M} \mathrm{LiCl}$, 1\% CTAB, 2\% PVPP (addition of PVPP is optional)] in the amount of 1 $\mathrm{ml}$ was added to the samples and ground once more in the buffer. After the samples were taken to the $1.5 \mathrm{~mL}$ eppendorf tubes, 0.2\% B-mercaptoethanol was added. The solution was incubated in $65^{\circ} \mathrm{C}$ water bath for $15 \mathrm{~min}$. Following these incubation periods, samples were cooled to room temperature, $0.5 \mathrm{~mL}$ chloroform:isoamyl alcohol $(24: 1[\mathrm{v} / \mathrm{v}])$ was added and mixed well (no vortex). Then, samples were centrifuged at $17.000 \mathrm{~g}(14.000 \mathrm{rpm})$ for 2 min, and the supernatant was transferred to a fresh tube $(\sim 0.8 \mathrm{~mL})$. Equal volume of isopropanol was added to the supernant and mixed gently by inversion several times. Incubation of the samples for at least $15 \mathrm{~min}$ on ice increased the efficiency of DNA yield. The samples were then centrifuged for $2 \mathrm{~min}$ at $17.000 \mathrm{~g}$ (14.000 rpm). Supernatant was discarded and $1 \mathrm{~mL} 70 \%$ ethanol was added. The samples were then centrifuged for $1 \mathrm{~min}$ at 17.000 g $(14.000 \mathrm{rpm})$. The pellet was once more washed with $70 \%$ ethanol optionally and air-dried until all ethanol was removed. The obtained nucleic acids as a pellet were dissolved in an appropriate amount of TE buffer (10 mM Tris-HCl [pH 8], 1 mM EDTA) (30 $60 \mu \mathrm{L})$. The nucleic acids dissolved in TE buffer, were treated with $1 \mu \mathrm{L}$ of ribonuclease $A(10 \mathrm{mg} / \mathrm{mL})$ and stored at $-20^{\circ} \mathrm{C}$ until use. Concentration and purity of extracted DNA were measured at OD 260 and by measuring $260 \mathrm{~nm} / 280 \mathrm{~nm}$ absorbance ratio by nanodrop (NanoDrop ND-1000 Spectrophotometer, Thermo Scientific, Wilmington, USA), respectively. The integrity of the extracted DNA was also evaluated by electrophoresis.

ITS region (ITS1F-5.8-ITS4) was amplified by PCR using the primers ITS 1F was designed specificly for fungal sequences (5'-CTTGGTCATTTAGAGGAAGTAA-3') (32) for the 3 ' end of $18 \mathrm{~S}$ rDNA and ITS4 was described as a universal primer (5'-TCCTCCGCTTATTGATATGC-3'), (29) for the 5' end of 28S rDNA. PCR amplifications for sequence analysis were performed in a $50 \mu \mathrm{L}$ volume containing $30 \mathrm{ng}$ of genomic DNA, $5 \mu \mathrm{L}$ of $10 \times$ reaction buffer, $2.5 \mathrm{mM} \mathrm{MgCl} 2,0.4 \mu \mathrm{L}$ dNTPs $(10 \mu \mathrm{M}), 0.2 \mu \mathrm{M}$ of each of the primers, and $1 \mathrm{U}$ Taq polymerase (Fermentas, Canada). The thermal cycling for PCR comprised incubation at $94{ }^{\circ} \mathrm{C}$ for 3 min, and 35 cycles, each with $94{ }^{\circ} \mathrm{C}$ for $30 \mathrm{sn}$, $52-54{ }^{\circ} \mathrm{C}$ for $1 \mathrm{~min}$, and extension of $1 \mathrm{~min} 30 \mathrm{~s}$ at $72{ }^{\circ} \mathrm{C}$ for $8 \mathrm{~min}$. Two separate PCR reactions were carried to amplify rDNA (ITS) regions of DNA. In order to prevent non-specific bands appeared in some reactions the annealing temperature was increased to $54{ }^{\circ} \mathrm{C}$ in some cases. The amplified PCR products were purified using Beckman Coulter Genomel Lab DTCS Quick Start Kit according to manufacturer's instruction. PCR products and DNA markers (100 bp, Fermentas, Canada) were analyzed by electrophoresis in 1.2\% agarose gel (AppliChem, Canada), containing $0,5 \mu \mathrm{L} / \mathrm{mL}$ ethidium bromide, for $2 \mathrm{~h}$ at $100 \mathrm{~V}$.

After PCR amplification of the entire ITS region (ITS1-5.8S-ITS2), all species analyzed displayed a single band of PCR products of about $600 \mathrm{bp}$. The amplified fragments with the primers ITS1F and ITS4 
comprising 3' end of small subunit gene, ITS $1 \mathrm{~F}$, the 5.8 S gene, ITS 4 and the 5' terminus of the large subunit gene, were sequenced. Sequence reactions were purified using the Beckman Coulter Agencourt Clean SEQ kit. The PCR products were sequenced by the cycle sequencing method using dye terminator cycle sequencing kit (Amersham Pharmacia, USA) according to the manufacturer's protocol. The purified and dried PCR-products were sent to Ankara University Biotechnology Institute for sequencing using the PCR primers. DNA sequence analysis was carried with Beckman coulter CEQ 8000 Genetic Analysis System in Biotechnology Institute.

\section{Data Analysis}

Chromatograms were manually checked using Chromas 2.01 (Chromas version 2.01; www. technelysium.com.au.chromas.html). The alignment of sequences (including out-group taxon) was done using CLUSTAL X2 (33). Two separate sequences which were obtained from one sample with forward (ITS1F) and reverse (ITS 4) primers derived from the ITS region were matched by the help of Clustal X2 programme. For comparison, lecideoid species from other parts of the world was sequenced and included in the data matrix together with one sequence downloaded from GenBank database (www.ncbi. nim.nih.gov) as shown in Table 2. Alignment of the sequences was performed visually, as gaps were few and easily interpreted. Insersion/deletion gaps were treated as missing data.

All data were analysed by Molecular Evolutionary Genetics Analysis (MEGA) 4 and a bootstraped dendogram was generated (34). To test for potential conflict, parsimony bootstrap analyses were performed on each individual dataset, and $75 \%$ bootstrap consensus trees were examined for conflict. Maximum Composite Likelihood analyses were performed using the program MEGA 4 (34). Bootstrapping was performed based on 1000 replicates with random sequence additions. Homoplasy levels were assessed by calculating consistency index $(\mathrm{Cl})$, retention index $(\mathrm{RI})$, and rescaled consistency $(\mathrm{RC})$ index from each parsimony search.

Table 2. Localities and their GenBank accession numbers

\begin{tabular}{|c|c|c|}
\hline Species & GenBank No & Origin \\
\hline Lecanora rupicola & AY541259 & Austria \\
\hline Lecanora rupicola & AY541265 & Austria \\
\hline Lecanora bicincta & AY541242 & Austria \\
\hline Lecanora bicincta & AY541243 & Austria \\
\hline Lecanora albella & AY541241 & Austria \\
\hline Lecanora farinacea & AY541261 & Austria \\
\hline Lecanora farinacea & AY541262 & Austria \\
\hline Lecanora carpinea & AY541246 & Austria \\
\hline Lecanora carpinea & AY541247 & Austria \\
\hline Lecidella elaeochroma & AY541275 & Austria \\
\hline Lecidella elaeochroma & EU266082 & Korea \\
\hline Lecidella stigmatea & JN873901 & Austria \\
\hline Lecidella stigmatea & JN873902 & Austria \\
\hline Lecidella patavina & JN873893 & Austria \\
\hline Lecidella patavina & JN873894 & Austria \\
\hline Lecidella carpathica & DQ534471 & Korea \\
\hline Lecidella carpathica & AY541274 & Austria \\
\hline Lecidea atrobrunnea & HQ650657 & Germany \\
\hline Lecidea atrobrunnea & GU074455 & Austria \\
\hline Lecidea atrobrunnea & GU074457 & Austria \\
\hline Lecidea fuscoatra & EU263922 & Austria \\
\hline Lecidea fuscoatra & HQ650662 & Germany \\
\hline Lecidea plana & EU259903 & Austria \\
\hline Lecidea plana & EU259904 & Austria \\
\hline Porpidia macrocarpa & EU263923 & Austria \\
\hline Porpidia speirea & HQ650631 & USA \\
\hline Ganoderma applanatum & GU256764 & USA \\
\hline
\end{tabular}




\section{RESULTS}

The lichen genus Lecidea was struck together with the substrate and it was so hard to collect genus during field works. Therefore only 0.001 $0.08 \mathrm{gr}$ lichen samples were obtained from substrate. According to DNA extraction results, the concentrations of DNAs were approximately in the range of $34.09-933.5 \mathrm{ng} / \mu \mathrm{L}$ and $260 \mathrm{~nm} / 280 \mathrm{~nm}$ ratios. Purity of DNA was between 0.59-1.72.

In this study, rDNA (ITS) regions of four species from genus Lecidea, three species from genus Lecidella, three species from genus Porpidia and one species Lecidoma were amplified by using ITS1F forward and ITS4 reverse primers with the help of PCR and sequenced by genetic analyzer to reveal genetic similarities and variations among the specimens. A sequence matrix of 4100 nucleotide positions were analysed and had 747 variable positions, of which 336 were parsimony-informative sites were detected (34). The number of base substitutions

Table 3. Estimates of evolutionary divergence over sequence pairs between groups

\begin{tabular}{lccccc}
\hline A & B & C & D & E & OG \\
\hline 1. A & & & & & \\
2. B & 0.024 & & & & \\
3. C & 0.130 & 0.095 & & & \\
4. D & 0.053 & 0.023 & 0.100 & & \\
5. E & 0.043 & 0.061 & 0.076 & 0.076 & \\
6. OG & 0.241 & 0.187 & 0.204 & 0.198 & 0.179 \\
& & & & & \\
A: Lecida & C: Lecidoma & E: Porpidia & & \\
B: Lecidella & D: Lecanora & OG: Out Group &
\end{tabular}

per site from averaging over all sequence pairs between groups was shown Table 3. All results were based on the pairwise analysis of 44 sequences (27 samples obtained from GenBank+17 samples obtained from Turkey). Analyses were conducted using the Minimum Evolution (ME) method in MEGA 4. According to the analysis genus Porpidia was the closest to genus Lecidea with 0.043 distance index. Genus Lecidoma was the second with 0.053 distance index. Ganoderma applanatum was very distant to all studied samples with 0.179-0.241 genetic distance index (Table 3). When transitional changes were compared transversional ones, bias towards transversional changes were observed, with the transition pair value of 56 versus transversional value of 54 (Table 4). Dendograms were obtained according to different phylogenetic methods such as Neighbour-Joining (NJ), Minimum Evolution (ME), Maksimum Parsimony, UPGMA using the software MEGA 4. Bootstrapping was performed based on 1.000 replicates with random sequence additions. To test for potential conflict, parsimony bootstrap analyses were performed on each individual dataset, and $75 \%$ bootstrap consensus trees were examined for conflict. Homoplasy levels were assessed by calculating consistency index $(\mathrm{Cl})$, retention index (RI), and rescaled consistency (RC) index from each parsimony search. The trees yielded similar topology showing only slight rearrangements within the groups. Since the topologies of the MP; ML, NJ and UPGMA analyses did not show any strongly supported conflicts, only Minimum-Evolution (ME) dendogram was shown in Figure 1.

Table 4. Numbers and base pairs of compared samples

\begin{tabular}{|c|c|c|c|c|c|c|c|c|c|c|c|c|}
\hline $\begin{array}{l}\text { Related } \\
\text { region }\end{array}$ & ii & si & sv & $R=s i / s v$ & TT & $\mathrm{TC}$ & TA & TG & $\mathrm{CC}$ & CA & CG & AA \\
\hline \multirow[t]{3}{*}{ ITS region } & 382 & 56 & 54 & 1.03 & 84 & 37 & 11 & 11 & 110 & 14 & 19 & 79 \\
\hline & AG & GG & TOTAL & & & & & & & & & \\
\hline & 19 & 109 & 491.79 & & & & & & & & & \\
\hline
\end{tabular}

$\mathrm{ii}=$ Identical Pairs, $\quad \mathrm{si}=$ Transitionsal Pairs, $\quad \mathrm{sv}=$ Transversional Pairs, $\quad \mathrm{R}=\mathrm{si} / \mathrm{sv}$ 
It was observed that the species were divided into two branches and both of them showed binary branches according to dendogram obtained from Minimum Evolution (ME) analysis. G. applanatum (GU256764) species constructed one of the branches while the other species clustered on the other branch (Figure 1). A result of the Minimum Evolution (ME) analysis without out-group (G. applanatum) four major clades were formed. Generally the species which were belong to the same genus, combined in one branch towards to the origin. According to dendogram, species from genus Lecidea were close to species from Porpidia genus phylogenetically, while the species from Lecidella genus located on a separate branch from the species in Lecidea and Porpidia genus (Figure 1). Lecidea fuscoatra

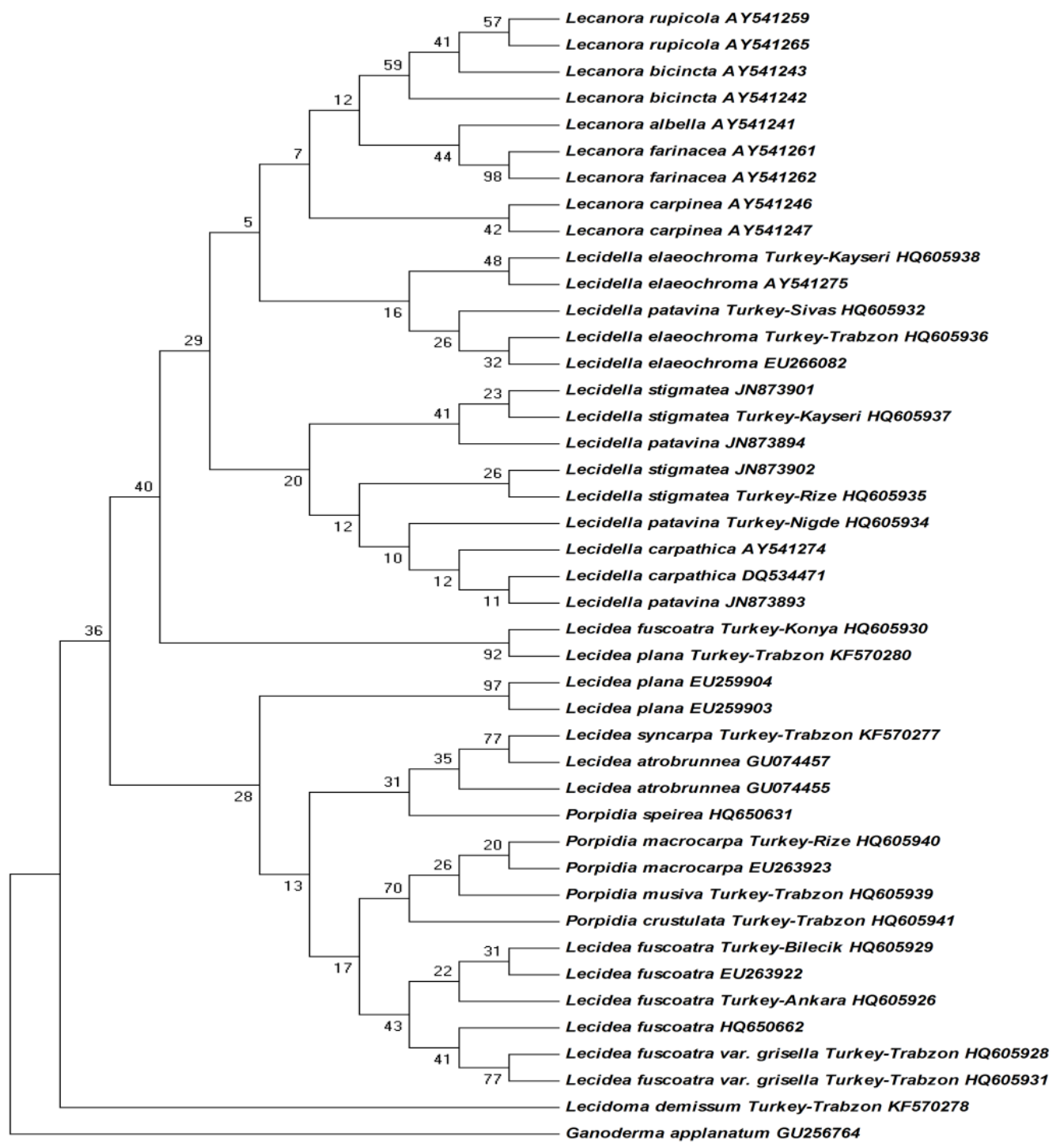

Figure 1. Minimum Evolution analysis inferred from ITS region sequences which is shown phylogenetic relations of 17 samples from Lecidea, Lecidella, Lecidoma and Porpidia genus. Numbers at the nodes are bootstrap frequencies above $40 \%$. 
which was collected from two different provinces of Konya was located on a separate branch from Ankara, Bilecik and Trabzon L. fuscoatra samples. Thus, it showed genetic difference from the other samples (Figure 1). Porpidia musiva species showed phylogenetic proximity to Porpidia species while $P$. macrocarpa showed phylogenetic proximity to $P$. crustulata species. Two of Lecidella patavina and Lecidella stigmatea samples which were collected from different localities were located on a separate branches. These two species showed proximite branches (Figure 1). Trabzon and Korea (EU266082) Lecidella elaeochroma samples showed boot strap value (32\%) and they formed a group. Also BakırdağKayseri and Austria (AY541275) samples of the same species showed boot strap value (48\%) and formed another group (Figure 1).

The results of this phylogenetic analysis indicates that four distinct lineages of Lecidea sp. and related genus occur in Anatolia, Turkey. Four dendograms were obtained according to different phylogenetic methods. The trees yielded similar topology showing only slight rearrangements within the groups. We demonstrated only Minimum-Evolution dendogram because analysis with Maximum Parsimony (MP) and Minimum-Evolution revealed trees with similar topology with slight differences among the groups and within groups.

\section{DISCUSSION}

The diversity of lichens, especially crustose species, is still poorly known (35). To overcome difficulties with the morphology based species delimitations in these groups, we evaluated molecular data (nuclear ITS and rDNA sequences) to test species boundaries within the genus Lecidea (35). Molecular data are largely absent for Turkey lichens, with only a few exceptions $(36,37)$. To overcome difficulties of assessing species diversity in Turkey lecideoid lichens, we employed molecular data (nuclear ITS ribosomal DNA sequences) to test species boundaries. Based on our phylogenetic estimate we re evaluated morphological characters to identify characters that can be used to identify these distinct lineages. Here we have focused on samples belonging to the genus Lecidea, Lecidella and Porpidia.

Ruprecht et al. (35), sampling was done along a north-south transect at five different areas in the Ross Sea region. Phylogenetic analyses also include specimens from other regions in Antarctica and non-Antarctic areas. According to their results, maximum parsimony, maximum likelihood and Bayesian analyses agreed in placing the samples from continental Antarctica into four major groups. Based on this phylogenetic estimate, their restudied the micromorphology and secondary chemistry of these four clades to evaluate the use of these characters as phylogenetic discriminators. These clades are identified as the following species Lecidea cancriformis, $L$. andersonii as well as the new species L. polypycnidophora Ruprecht \& Turk sp. nov. and another previously unnamed clade of uncertain status, referred to as Lecidea spp. (35). Ruprecht et al. demonstrate that the diversity of Lecidea spp. in continental Antarctica is higher than previously thought (35). Geographical data evaluation also shows a decreasing diversity of Lecidea species the more continental and drier the habitats are. It clearly indicates that the species concept in Lecidea needs revision and that molecular data are helpful in interpreting subtle morphological differences that have been previously regarded as intraspecific variability (35).

This is especially true for crustose lichens that are often reduced to minute patches surrounding ascomata under the harsh climatic conditions typical of this ecosystem. The number of available collections is limited, which restricts the ability to assess variability within species. Because of the 
poor understanding of morphological and chemical variation, their taxonomy is currently in urgent need of revision. Lecideoid lichens often act as pioneers on rock and pebbles (38). Saxicolous lecideoid lichens in Turkey include species of the genera Carbonea, Lecanora, Lecidea, and Lecidella. Despite the ecological importance of these lichens in polar habitats, the taxonomy is only poorly known and the circumscription of taxa differs between authors.

According to Buschbom and Mueller (3) the lichen-forming genus Porpidia (Porpidiaceae, Ascomycota) provided excellent opportunities for evolutionary, reproductive, and ecological studies of crustose epilithic lichen symbioses. Separate and combined analyses of nuclear ribosomal RNA large subunit and nuclear B-tubulin gene fragments were performed using maximum parsimony, maximum likelihood, and Bayesian approaches in their study. Branch support was estimated using non-parametic bootstrapping and posterior probabilities, while monophyly of a priori defined groups was tested using posterior probabilities. The results revealed a highly supported "Porpidia sensu lato," however, Porpidia itself was not monophyletic. Several smaller genera of the Porpidiaceae and probably the large genus Lecidea (Lecideaceae) were nested within the group (3). The present study was also indicated that the species of the genus Porpidia are nested within Lecidea as shown in previous study.

A large percentage of crustose lichens on rock with large black apothecia (more than $0.75 \mathrm{~mm}$ in diameter) belong to Porpidia genus. Other crustose lichens that are superficially similar with a hand lens include species of Lecidea, Rhizocarpon, Sarcogyne and Buellia. P. crustulata together with the very similar $P$. macrocarpa, make up the bulk of the nonpruinose species of Porpidia (5). In our study, $P$. crustulata and $P$. macrocarpa composed a close branch on the three that is supported with a $96 \%$ bootstrap value. In P. macrocarpa, the apothecia tend to be a larger (up to $3.5 \mathrm{~mm}$ in diameterpor crus $0.13-1.5 \mathrm{~mm}$ in diameter); the spores are larger $(13-23 \times 7-10 \mu \mathrm{m}$ other $10-17 \times 5-9 \mu \mathrm{m})$ the hymenium is higher $(80-120 \mu \mathrm{m}$ other $60-90 \mu \mathrm{m})$, and cells of the exciple are smaller (mostly 3-6 $\mu \mathrm{m}$ in diameter other 5-8 $\mu \mathrm{m}$ ). The gelatinous halo around the spores helps distinguish species with 2-celled spores from similar species of Buellia or Catillaria. Porpidia has 1-celled spores and a different ascus type. Lecidea species have much smaller, 1-celled spores, and their paraphyses are mostly unbranched (5). According to our study result of phlogenetic analyses and morphological characters of species in Anatolia, Turkey were similar results.

The Porpidia genus is one of the most studied of the segregates of Lecidea $(2,3,7,9-11)$. The reasons for this are largely because of the difficulty in recognizing species-level characters within the genus. Most species of Porpidia have a grey thallus and black sessile apothecia and, as macroscopic characters (e.g. thickness of thallus, size of apothecia) appear to be extremely variable within a single species, specimens are usually impossible to identify beyond genus in the field (5). It was aim of the study molecular studies of the Lecidea genus and related genus have greatly enhanced our understanding of the infrageneric relationships, thus permitting a reassessment of morphological characters that should result in a clearer understanding of species concepts within the genus.

The analyses of Buschbom and Mueller indicated that the genus Porpidia could be divided into three infra-generic groups, with a high probability that the Lecideaceae s. str. (i.e. Lecidea and Cecidonia) was nested within them (3). This suggested that either the Porpidiaceae should be included within the Lecideaceae (and Porpidia within Lecidea), or that Porpidia should be divided into at least three, and possibly four, separate genera. According to our results, species of Porpidia genus in Anatolia, Turkey 
remained relatively close to Lecidea group samples. However, Buschbom and Mueller (3) studied only a limited number of the relevant taxa, and because of the lack of consistent supporting morphological/ chemical differences, they preferred to await the results of further analyses of all the available character systems (molecular, morphological, and chemical) before making any taxonomic innovations. P. crustulata is a common species in upland and montane habitats. It is an early colonizer of bare rock surfaces and is frequent around areas of prolonged snow-lie. It is distinguished from $P$. macrocarpa in the field by its smaller apothecia and microscopically by its smaller ascospores, lower thecium and thicker excipular hyphae (5).

Lecidella may be hard to distinguish from other black disk lichens such as Lecidea, Porpidia or Buellia. They are, however, fairly easy to recognize under the microscope by the combination of their easily separating paraphyses, greenish tissues, and broad spores (5). In the current study Porpidia was the closest to genus Lecidea. Lecidella carpathica differs mainly in its dark yellowish brown hypothecium and darker exciple; it contains atranorin and diploicin (an orcinol depsidone). Lecidella carpathica which were obtain from GenBank located on a separate branch from the species in Lecidea, Lecidella and Porpidia genus. Because of these reasons could be explained synerjistic effect of the seconder metabolite. Lecidella patavina (syn. L. spitsbergensis) has the same chemistry as L. stigmata, but its hymenium is filled with oil drops, its exciple contains crytals, and the thallus tends to be thicker. Lecidella elaeochroma located on a separate branch from the other Lecidella species because of this result Lecidella elaeochroma which differs only in its C positive orange thallus (arthothelin).

Dissimilarity index and dendrogram data which are conducted as a result of this research reveals the genomic similarities and differences of studied samples. By determining molecular phylogeny of the samples showing the variation in different habitats and populations, certain taxonomic values have revealed. The distant taxa relations have been defined by ITS region amplification and sequencing. Wide range of information is provided on Anatolia, Turkey of Lecidea and Lecidella, Porpidia samples. A molecular study involving the Lecidea, Lecidella and Porpidia species that are present in Anatolia, Turkey have not been carried out so far. Furthermore these genus are quite less molecular studies in the world literature. Thus, current study is the first report on Lecidella, Porpidia genus in the world.

Lichens are major sources of biodiversity in terms of wide variety of species in Anatolia. If the study extends by using more species and localities, ITS variations among the species involving Lecidea, Lecidella and Porpidia will help to enlighten evolutional differentiation of the lichens. Those type of studies will make contribution to reveal and protect the rich gene potential of Turkey. It is truly important that those type of studies will be very beneficial to find solutions to the taxonomic problems of certain samples and to reveal their position in lichen systematic on molecular dimension.

\section{ACKNOWLEDGEMENTS}

This study was supported by Ankara University, Management of Scientific Research Projects (no. 2006-0705116). We gratefully acknowledge for M. Gökhan Halıcı's assistance with the collection and identification some lichen species. 


\section{REFERENCES}

1. Hertel H. Schlüssel für die Arten der Flechtenfamilie Lecideaceae in Europa. Biblioth Lichenol, 1995; 58: $137-80$.

2. Hertel H. Ein vorlaufiger Bestimmungsschlüssel für die kryptothallinen, schwarzfrüchtigen, saxicolen Arten der Sammelgattung Lecidea (Lichenes) in der Holarktis. Decheniana, 1975; 127: 37-78.

3. Buschbom J, Mueller G. Resolving evolutionary relationships in the lichen-forming genus Porpidia and related allies (Porpidiaceae, Ascomycota). Mol Phylo Evol, 2004; 32: 66-82.

4. Hertel H. Revision einiger calciphiler Formenkreise der Flechtengattung Lecidea. Nova Hedwig Beih, 1967; 24: 1-174.

5. Brodo IM, Sharnoff SD, Sharnoff S. Lichens of North America, Yale University Press. London, 2001; 390633.

6. Ahmadjian V. The lichen symbiosis. New York, Wiley, 1993; 135-40.

7. Gowan SP. The lichen genus Porpidia (Porpidiaceae) in North America. Bryologist, 1989; 92: 25-59.

8. Gowan SP. A character analysis of the secondary products of the Porpidiaceae (lichenized Ascomycetes). System Bot, 1989; 14: 77-90.

9. Gowan SP, Ahti T. Status of the lichen genus Porpidia in eastern Fennoscandinavia. Annal Bot Fenn, 1993; 92: 25-59.

10. Knoph JG. Vorarbeiten zu einer monographie der euthallinen arten der flechtengattung porpidia (Porpidiaceae, Lecanorales) Europas, mit besonderer Berücksichtigung des Alpengebietes. Staatsexamensarbeit, Universitat München, 1984.

11. Schwab AJ. Rostfarbene Arten der Sammelgattung Lecidea (Lecanorales): Revision der Arten Mittelund Nordeuropas. Mitteilungen der Botanischen Staatssammlung München., 1986; 2: 221-476.
12. Fryday AM. Ecology and taxonomy of montane lichen vegetation in the British Isles. Ph. D. Thesis, University of Sheffield, England, 1997.

13. Körber G. Systema Lichenum Germaniae (I-XXXIV). Die Flechten Deutschlands mikroscopisch geprüft, kritisch gesichtet, charakteristisch beschrieben und systematisch geordnet, Breslau, 1855.

14. Zahlbruckner A. Catalogus Lichenum Universalis. Vol. 3, Leipzig, 1925.

15. Fries TM. Lichenographia Scandinavica. Pars I u. II, Uppsala, 1874.

16. Hertel H, Leuckert C. Über Flechtenstoffe und Systematik einiger Arten der Gattungen Lecidea, Placopsis und Trapelia mit C+ rot reagierendem Thallus. Willdenowia, 1969; 5: 369-83.

17. Knoph JG. Untersuchungen an gesteinsbewohnenden xanthonhaltigen Sippen der Flechtengattung Lecidella (Lecanoraceae, Lecanorales) unter besonderer Berücksichtigung von auBereuropaischen Proben exklusive. Am Bibliog Lichen, 1990; 36: 1-183.

18. Leuckert C, Knoph JG, Ziegler HG, Hertel H. Chemotaxonomische studien in der Gattung Lecidella (Lecanoraceae, Lecanorales) I. Lecidella carpathica und Lecidella viridans-Untersuchungen an mittel- und südeuropaischen Proben. Herzogia, 1990; 8: 265-72.

19. Leuckert C, Knoph JG, HertelH. Chemotaxonomische Studien in derGattung Lecidella (Lecanoraceae, Lecanorales) II. Europaische Arten der Lecidella asema-Gruppe. Herzogia, 1992; 9: 1-17.

20. Leuckert C, Knoph JG. European taxa of saxicolous Lecidella containing chloroxanthones: identification of patterns using thin layer chromatography. Lichennologist, 1992; 24: 383-97.

21. Huneck S, Santesson J. Mitteilung über Flechteninhaltsstoffe. Die Inhaltsstoffe von Lecidella carpathica (Koerb.) Szat. Und die Struktur des Thuringions, eines neuen Xanthons. Zeitsc für Naturfor, 1969; 24b: 756-60.

22. Elix JA, Crook CE. The joint occurrence of chloroxanthones in lichens, and a further thirteen new lichen xanthones. Bryologist, 1992; 95: 52-64. 
23. Song KM, Osborn TC, Williams PH. Brassica taxonomy based on nuclear restriction fragment length polymorphisms (RFLPs), I. Genome evolution of diploid and amphidiploid species. Theor App Genet, 1988; 75: 784-94.

24. Miller JC, Tanksley SD. RFLP analysis of phylogenetic relationships and genetic variation in the genus Lycopersicon. Theor App Genet, 1990; 80(4): 437-48.

25. Wheeler WC, Honeycutt RL. Paired sequence difference in ribosomal RNAs: evolutionary and phylogenetic implications. Mol Biol Evol, 1988; 5: 90-6.

26. Bridge PD, Arora DK, Reddy CA, Elander RP. Applications of PCR in Mycology. In: PCR Applications in Studies of Lichen-Forming Fungi (Crespo A, Cubero OF and Grube M, eds. USA: Cab International, 1998; 231-69.

27. Dizkırıcı A, Kaya Z, Cabi E, Doğan M. Phylogenetic relationships of Elymus L. and related genera (Poaceae) based on the nuclear ribosomal internal transcribed spacer sequences. Turk J Bot, 2010; 34: 467-78.

28. Torres RA, Gunal M, Humleben V. GC balance in the International Transcribed Spacers ITS1 and ITS2 of nuclear ribosomal RNA genes. J Mol Evol, 1990; 30: 170-81.

29. White TJ, Bruns T, Taylor J. Amplification and direct sequencing of fungal ribosomal genes for phylogenetics. In: PCR protocols: A guide to Methods and Applications (Innis MA, Gelfand DH, Sninsky JJ, White TJ, eds. San Diego: Academic press, 1990; 315-22.

30. Porter $\mathrm{CH}$, Collins FH. Species-diagnostic difference in a ribosomal DNA internal transcribed spacer from the sibling species Anopheles freeborni and Anopheles hermsi (Diptera: Culicidae). Am J Trop Med Hyg, 1991; 45: 271-9.
31. Aras S, Cansaran D. Isolation of DNA for sequence analysis from herbarium material of some lichen species. Turk J Bot, 2006; 30: 449-53.

32. Gardes M, Bruns TD. ITS primers with enhanced specificity for basidiomycetes-application to the identification of mycorrhizae and rusts. Mol Ecol, 1993; 2: 113-8.

33. Larkin MA, Blackshields G, Brown NP, Chenna $\mathrm{R}$, McGettigan PA, McWilliam $\mathrm{H}$, et al. Clustal W and Clustal $X$ version 2.0. Bioinformat, 2007; 23: 2947-48.

34. Tamura K, Dudley J, Nei M, Kumar S. MEGA4: Molecular evolutionary genetics analysis (MEGA) software version 4.0. Mol. Biol. Evol., 2007; 24: 1596-99.

35. Ruprecht $\mathrm{U}$, Lumbsch $\mathrm{T}$, Brunauer $\mathrm{G}$, Allan-Green TG, Turk R. Diversity of Lecidea (Lecideaceae, Ascomycota) species revealed by molecular data and morphological charaers. Antar Sci, 2010; 22(6): 727-41.

36. Aras S, Cansaran D, Türk AÖ, Kandemir I, Candan M. Resolving genetic relationships in manna group of lichens from genus Aspicilia. Afr J Biotech, 2007; 6(9): 1154-60.

37. Cansaran D, Aras S, Kandemir I, Halıcı MG. Phylogenetic relations of Rhizoplaca Zopf. From Anatolia Inferred from ITS sequence data. Zeit Naturfor, 2006; 61c: 405-12.

38. Hertel H. Progress and problems in taxonomy of Antarctic saxicolous lecideoid lichens. Bibliot Lichenol, 1987; 25: 219-42. 